\title{
INTRODUCTION: INTEGRATION THROUGH CRISES
}

\author{
Valerie J. D'Erman and Amy Verdun (co-editors)
}

University of Victoria

\begin{abstract}
The introductory paper to this Special Issue discusses the idea of crisis in relation to European integration from a historical perspective in order to contextualize four different current events in the European Union (EU) in turn - euro area crisis, migration crisis, Brexit, and the rise of populist responses to EU governance. We turn to the wider scholarly concept of 'crisis' and apply it to large-scale events affecting the EU, in order to relate events to broader theoretical discussions about the progression of the EU. Existing literature on the topic highlights different varieties of crisis scenarios: those that undermine the basic integrity of the undertaking; those that threaten certain domains or the activities of certain groups; and those that reflect short-term, but acute dangers that may be overcome without structural damage. This introductory contribution situates each of the four above-mentioned 'crises' in the context of these varieties and offers suggestions for how each crisis might influence the future direction of European integration by using illustrations from each of the articles in this special issue.
\end{abstract}




\section{Introduction}

This paper discusses the idea of crisis in relation to European integration from a historical perspective in order to contextualize four different current events in the European Union (EU) in turn - euro area crisis, migration crisis, Brexit, and the rise of populist responses to EU governance. It briefly discusses the specific nature of each event, or 'crisis,' and relates each event to broader theoretical discussions about progression of the EU. This Special Issue of the Review of European and Russian Affairs presents the work of junior scholars who have each respectively examined different crisis-related situations affecting European countries and European integration. In this introduction, we turn to the wider scholarly concept of 'crisis' and apply it to large-scale events affecting the EU, some of which are not dealt with specifically in the articles that follow.

Existing literature on the topic highlights different varieties of crisis scenarios: those that undermine the basic integrity of the undertaking; those that threaten certain domains, or the activities of certain groups; and those that reflect short-term but acute dangers that may be overcome without structural damage. This introductory contribution situates each of the four above-mentioned 'crises' in the context of these varieties, and offers suggestions for how each crisis might influence the future direction of European integration, by using illustrations from each of the articles in this special issue.

The central concept of 'crisis' in the EU underscores two important aspects of general understandings of European integration. The first is that the basic definition of the noun 'crisis' has three components: crisis as a time of intense difficulty or danger; crisis as a time when a difficult or important decision must be made; and crisis as the turning point of a disease when an important change takes place, indicating either recovery or death (Oxford English Dictionary 2017). These three components are interrelated in that they are not mutually incompatible in defining the same situation, and yet each of the three components suggests a different point or perspective of a situation. Scholarly work on the concept of crisis as it relates to the contextualization of risk and responsibility is also relevant here, as such work highlights the social processes involved both in defining an event as a crisis and in assigning a level of severity to it. Given the above definition and the recognition that the label 'crisis' is vulnerable to political machinations, we argue that, in practice, a crisis can be understood as existing on something of a spectrum whose extremes are identified as 'a problem' and 'full chaos.' Analyses of events unfolding in the EU ought to be understood as comprising different points on this spectrum, with attendant possibilities of disaster and/or opportunities.

The second aspect of crisis, in particular as it relates to the EU, is the notion that integration progresses in response to crises, frequently in unintended directions. This very idea has its roots in the Monnet Plan and in the Schuman Declaration, with the crises of war and reconstruction galvanizing the possibility of combining resources and leading to the 1951 Treaty of Paris. This process continues with major historical events in modern European integration that mark significant turning points in the development of supranational governance, such as the Empty Chair crisis in 1965, the Constitutional crisis in 2005 (following the French and Dutch referendums on the Constitutional Treaty), or short-term setbacks with treaty ratifications such as with Maastricht in 1992 or Lisbon in 2007 (Stone Sweet and Sandholtz 1997; Verdun 2000; Dinan 2010). Although the idea of crisis heralding progression is not a new one, the application of this idea to the four events discussed in this introduction serves to remind us that, in the case of the EU, 
progression is not necessarily movement toward a knowable defined finalite - meaning, the idea of progression should not be confused with the idea of EU governance arriving at the stage of full federation, or even as a consistent trajectory of increasing peace and prosperity. Rather, the idea of progress can also simply be the movement of European integration in any positive or negative direction that heralds change (Schmitter 1970: 840). This reminder is useful when analyzing current events in the EU, as it helps to situate each crisis in the context of movement, without adhering too strictly to normative prescriptions of how the status quo of integration ought to be maintained.

This article begins with a review of the idea of crisis, both in a general policy context and in the narrower context of the EU. While most EU literature in this area arises from discussions of Economic and Monetary Union (EMU) and the euro area debt crises, the core arguments reflect the notion of a European response, and in doing so, the complexities of cultivating a shared response to the perception of a shared problem. Also related is the idea of democratic deficit, which some scholars frequently present not as a moment of urgency, but rather as a slow-burning, longterm crisis of legitimacy. We apply the review to four different situations confronting the EU and its members in a framework that considers the durability and elasticity of the European integration project. We conclude by drawing parallels to each of the articles in this special issue, and by offering predictions on which crises are most likely to have significant structural impacts.

\section{Survey of crisis in the EU}

The concept of crisis as it pertains to policy-oriented settings is inextricably linked to concepts of risk and regulation. Risk in public settings is bound up with the idea of a 'risk society,' which Giddens (1999) identifies as existing only in societies that have managed the majority of the natural world. In this sense, risk is distinct from hazard or danger, and comes only to societies that are post-tradition - meaning that people who live in worlds that are reasonably beyond the vagaries of nature are able to exercise the power of choice in areas that were previously left to fate alone. A risk can therefore also contain a positive element, as it engages with intentional brinksmanship in pursuit of values, and the strategies relevant to pursuing them, arising out of rational cost-benefit analyses. A risk society is "a society increasingly preoccupied with the future (and also with safety), which generates the notion of risk... The word refers to a world which we are both exploring and seeking to normalise and control" (ibid., 3). The 'manufactured risk' prevalent in post-traditional societies creates the need for a form of responsibility to attend to risk. Regulations, in the form of policy, become the main proxy for responsibility - a central example here being welfare state policies as a form of security to mitigate the most salient risks in an industrial society.

The field of sociology posits that the relationship between risk and crisis is embedded in the notion that a modern risk society should be equipped to manage the dangers of the world around us. Modernity conceptualizes risks as being manageable, leading to the logic of regulatory governance as rational calculability. A 'crisis' thus becomes "an example of the social processes of defining and reacting to risk and risk events," shaped in large part by the social construction of risk and the social perceptions of the event in question (Hutter and Lloyd-Bostock 2013, 386). The extension of this logic is that when regulations have not been successful in mitigating the risks of an event whether a natural disaster or a man-made disaster - an event becomes a crisis; the event itself is embedded in a particular social and cultural environment, which in turn shapes the tensions and 
political debates arising in response to the crisis. Applying the risk society thesis to questions of crises in the EU offers a window into the process of how an event becomes a crisis. Although trying to fit the mechanisms of EU governance into the idea of 'society' is obviously a stretch, the regulatory milieu of the EU provides a suitable example of how a crisis manifests itself, both practically and politically, through the social processes of risk and responsibility.

Literature on the history of European integration has generally upheld the notion that the EU itself progresses in response to crisis; that the predicament in question, more often than not, provides a critical juncture where key decision-makers are likely to be more open to alternative solutions. By this logic, depending on the nature of the crisis or the time-sensitivity surrounding its containment, the existence of crisis heightens the possibility of both national and supranational actors considering policy responses that either broaden or deepen the framework of European integration beyond the current status quo. In accordance with the risk society thesis, the value underlying the EU is of European integration providing solutions to the need for peace and prosperity. Events that threaten to interrupt the direction of integration are socially processed at the supranational level as crises. The strategies initiated by policy-makers to protect the value of integration develop out of a rational understanding of responsibility - the need to regulate in order to mitigate the potential for future similar crises to unfold. One stream of research that alludes to the relationship between crisis and European integration focuses on events internal to the EU to include the Empty Chair crisis of 1965 (Ludlow 1999; 2006), the Constitutional crisis of 2005 (De Witte 2005), and instances of 'crisis' when a member state rejected a EU treaty with a public referendum, such as Denmark did with the Maastricht Treaty in 1992 (Worre 1995), or Ireland with the Lisbon Treaty in 2008 (Özlem Atikcan 2015). In all cases, the crisis moment is defined by a denial of the proposed trajectory of supranational political development. However, the treaty rejections came from the voting public, who in each instance took the opportunity to express dissatisfaction of some sort with EU governance, whereas the rejection in the Empty Chair crisis came from the French government's objection to the financing plan proposed by the Hallstein Commission and the style of policy-making within the Commission itself. This distinction is perhaps not particularly noteworthy, as each rejection broadly conveys a reaction to the perception of an unacceptable renunciation of sovereignty, but it does highlight that objections concerning the substance of European integration are not necessarily always about a public-versus-elite dichotomy - relevant to our later discussion of populism. Each of the above crises was resolved with some form of political bargaining to appease the initial rejection. In the case of the failed Constitutional Treaty of 2005, the majority of French and Dutch voted against it in two subsequent referendums, resulting in an abandonment of the rejected proposal. With the benefit of hindsight, crises in these instances were important temporary roadblocks that re-routed the path of integration by recalibrating expectations and conceding gains in supranational authority.

Another stream of research focuses on events external to the EU institutions - political upheavals that were not the result of actions taken at the supranational level, but were rather major international events that had direct bearing on the course of European integration. The two most prominent (and related) instances are the collapse of the Soviet Union and German reunification. Each of these events generated immediate political action at both national and supranational levels of governance in member states with direct and visible consequences for the trajectory of the EU as a whole. In the case of the collapse of the Soviet Union, the sudden potential to enlarge the EU (then the European Community) from a Western European organization toward a pan-European entity fundamentally altered the course and content of integration (Laursen and Vanhoonacker 
1994). In the case of German reunification, the swift increase in the size and capability of one of the four large member states of the twelve EC member states, turning one of them into a clearly larger one, fundamentally changed the substances of policy proposals and the dynamics of political compromise, and was passed for political reasons without a Treaty change (Jacqué 1991). This point is worth noting simply because the size of a member state has (and has had) ramifications for various isolated areas of decision-making, such as the number of MEPs in the European Parliament, or various incarnations of qualified majority voting in the Council - although German reunification initially only led to a change in the number of MEPs (1994); voting weights in the Council only changed much later (i.e., Lisbon Treaty). Another EU development that was heavily affected by the change in intra-European power dynamics and geopolitical changes is the case of EMU. The Delors Report, presented in April 1989 (Verdun 1999), before there was a clear sign that the Berlin Wall would fall or that Eastern Europe would get rid of its communist regimes, was still 'pie in the sky' to many observers. However, once the geopolitical situation changed and Germany was seeking approval from its allies and other EU member states to unify, some projects such as EMU became more of a reality (Italianer 1993; Sandholtz 1993; Dyson 1994; Verdun 2000). Though neither of these events is portrayed as a crisis in the literature, the level of opportunity and change that each event provided meets the criteria for a broader definition of crisis being also a time when difficult or important decisions must be made. As a current parallel, Brexit provides another instance of a major change arising out of non-EU institutional dynamics that will have a direct impact on the future course of European integration.

In many ways, the euro crisis offers the most emblematic example of crisis in the history of the EU to date. The financial crisis that originated in the United States (US) in 2007 quickly spread across global markets. Once it fully hit the EU, it became clear that the EU was insufficiently prepared to deal with a crisis of this order of magnitude. The EU did not have the instruments to manage this multifaceted crisis and relied heavily on EU member states. When those member states did not agree with the path that needed to be taken to offset the crisis, it became a larger crisis that ended up putting the entire euro area at risk. At the height of the crisis, it seemed that Greece might default and leave the euro area, possibly with the risk of breaking up the euro area, as others might follow its example. At the eleventh hour, the crisis was managed, if not resolved. In the interim, the EU gained more powers (in the form of new mechanisms such as the European Semester, the 'Fiscal Compact,' and the European Stability Mechanism), but citizens became much less enthusiastic about the EU, with citizens in fall 2012 and spring 2013 dropping to their lowest support of the EU, in terms of the positive/negative image the EU conjures up. The topic of financial crisis may provide the clearest instance of all components of the above dictionary definition of 'crisis': a time of intense difficulty or danger (for some domestic euro area members and for the EU as a whole); a time when difficult or important decisions must be made (the immediacy of individual country bailouts, or larger decisions regarding the governance of EMU); and a turning point of a disease when an important change takes place, indicating either recovery or death (new mechanism and institutions created in response to the euro crisis that attempt to bolster the stability and durability of EMU).

Literature on this topic comprises pre-crisis works that were prescient of an eventual EMU emergency, as well as more recent research on the immediate effects of the euro area financial crisis. The former comprises those who identified that the asymmetry of EMU represented a nonoptimal currency area, recognizing that a monetary union without an accompanying fiscal union placed the euro area in a precarious position, should a significant economic downturn come to pass 
(Bayoumi and Eichengreen 1994, Dyson 1994, Krugman 1993, Verdun 2000), as well as those who predicted that political conflicts between EMU members over the scope and jurisdiction of the Maastricht Treaty in monetary affairs would be inevitable (Feldstein 1997). The latter group, growing in scope, identifies a number of areas both political and economic that have been and continue to be affected by financial crisis within the euro area (Menz and Smith 2013). These include discussions of political legitimacy (Schmidt 2014), analyses of domestic economies and the implications of austerity measures on these economies (Matthijs and Blyth 2015), and examinations of the panoply of EU responses to financial crisis in the context of theories of European integration (Schimmelfennig 2015; Jones et al. 2015; see also the special issue of the Journal of European Public Policy on the theme "European integration in times of crisis: theoretical perspectives" and the introduction by its editors Ioannou et al. 2015). In many ways, these two groups of scholarly work taken together drive home the argument that crisis is helpful, if not essential, to furthering movement in either direction in the process of European integration. Indeed, research shows that the actors in the policy-making process were willing to move forward on EMU despite the lack of an optimal currency area, precisely because of the perceived future spillover effects on economic policy-making (Verdun 2000, 196). The findings here demonstrate that EU member states and policy-makers were at the time not only aware of the possibility of financial crisis (although perhaps not of its likely extent when it actually arrived in 2008), but were to some degree even relying on an economic downturn as motivation to strengthen and deepen the integration of the euro area.

The paradox that the euro crisis presents is that, while its effects indeed demonstrate progress in institutional reforms targeting fiscal surveillance, banking union, and a degree of emergency funds, they also simultaneously reinforced debates over the effectiveness, appropriateness, and legitimacy of EMU as a whole. However, in applying the risk society thesis, there is perhaps no paradox at all, as the institutional features of EMU that galvanized the financial crisis in the euro area could instead be understood as a deliberate risk undertaken by EU policy-makers in order to attend to the greater perceived value of deeper integration. Furthermore, given that many European nations have been built at the end of a period of war or during a time of nation-state formation, the EU is being created currently in a piecemeal fashion. There is no grand plan. Hence, integration can only occur on a step-by-step basis. In the past, it has been clear that grand plans often lack support from a wider public or from key constituencies that need to approve it (e.g., the European Defence Community did not find support in the French parliament in August 1954; fifty years later, the 2004 Treaty Establishing a Constitution for Europe was voted down in referendums in France and the Netherlands in spring 2005). Thus, a proven strategy of European integration is to move step by step. The assumption is that when the limits of integration come to the fore, the politicians and publics will be better able to assess the issues at stake and why deeper integration is necessary.

It could be argued that the crisis of legitimacy is in many ways the broad umbrella under which all large-scale events internal to the EU might fall. The question of whether a democratic deficit exists in supranational governance - and if it does exist, what to do about it - has been posed by academics, policy-makers, and commentators for decades (Verdun 1998; Stavridis and Verdun 2001; Crombez 2003; Schmitter 2000). Early modern efforts at European integration, beginning with the European Coal and Steel Treaty, tend to be characterized as being supported by a 'permissive consensus,' whereby public perception of integrative efforts was markedly favourable and considered to be likely the result of direct memories of war, Cold War international politics, and the optimistic climate resulting from the establishment of the Common Market in 1962 - or 
some combination of these three variables (Inglehart 1967). The increased pace of integration set by the completion of the single market is one likely source of this crisis, as the post-war rationale for European integration collectively faded from being at the forefront of public consciousness concomitantly to EU governance becoming more tangibly visible to the public, as in the areas of citizenship, borders, and currency; the numerous national referendums held in response to the Maastricht Treaty and subsequent treaties reflect this slow trend, to some degree. The debate itself considers whether the EU has a sufficient democratic mandate from its citizens via indirect representation to govern at the supranational level, or whether the increase of EU-level governance has shaded into the realm of non-accountable technocracy. The EU's specific institutional forms of supranational governance create an uneasy space for contestation; although it possesses more mechanisms of democratic input than any other global governance institution, its non-state character obfuscates the link between input and output, and the lack of familiar processes of direct democracy compound this problem (Hurrelmann 2014).

Early post-war logic on the permissive consensus surrounding European integration does not extend to post-Maastricht developments, or at least does not extend easily without visible and tangible societal gains: "functionalism is not antithetical to myth, but on the contrary invokes a powerful myth of its own, namely that of modernity as rationalization" (Hansen and Williams 1999, 235). Exacerbating this problem are the new institutions created in response to financial crisis and the heavy-handed prescription of austerity measures accompanying bailout packages. Both measures have been criticized by citizens and political parties alike for being overly intrusive into national policy-making and domestic welfare states (Mény 2014). The tension arising from this perceived intrusion has led to more polarizing debates on potential solutions to democratic deficit: those that recommend increased fiscal federalism (Hallerberg et al. 2012), or deeper political integration towards more effective transnational governance (Habermas 2012), or both (Schure and Verdun 2018); and those that advocate diminishing the role of the EU and returning to more visible forms of sovereign governance (Zielonka 2014). The latter argument has frequently shaded into political platforms labelled as 'populist' by observers from numerous academic and journalistic circles (Offe 2015; Müller 2016), as the underlying logic reflects the idea of nationalism providing an immediate solution to the EU's democratic deficit.

The next section briefly examines four current 'crises' in the EU, and attempts to situate each event in the context of challenge to the logic of integration.

\section{Political, Economic, and Social Crises in the EU}

In considering different varieties of crisis scenarios and the impact of significant events on the trajectory of European integration, we examine four different events (ongoing at some level at the time of writing) affecting the integrity of the EU as a supranational institution: the euro area crisis, the migrant crisis, the rise of populism across numerous EU member states, and Brexit. While these four events are not all examined in equal depth in the articles of this special issue, we present them as significant to understanding the character and purpose of EU governance.

The euro area crisis, discussed in more detail above, represents the biggest challenge to the very justification of the EU's existence. Although economic in its origin, the crisis and its aftermath have visibly affected social policies normally understood to be the purview of domestic decision- 
making, such as employment levels and welfare state benefits. The encroachment of the EU into national political economies has helped shift the public perception of EMU from being a flagship success of the single market toward becoming the symbol of the downside of European integration (see also the recent Special Issue of Government and Opposition "Democracy without Solidarity: Political Dysfunction in Hard Times," edited by Erik Jones and Matthias Matthijs, in particular their introduction, Jones and Matthijs 2017). The extent of the euro area crisis brings into question issues of democratic legitimacy and economic technocracy, and - perhaps most critically for the structural health of the EU - challenges the logic of community in the face of real and present economic dangers. In terms of the potential for a crisis to reach a level of danger that disrupts the EU's entire undertaking, the euro area crisis poses a significant threat to the continued integrity of the union, when considering the arguments for technocratic decision-making systems across the euro area, and yet, it similarly meets the definition of crisis being a significant point of opportunity, when considering some of the new institutional mechanisms that have evolved in response to the crisis, such as the European Semester (Verdun and Zeitlin 2017).

The refugee crisis saw a massive influx of asylum seekers and other undocumented migrants coming into Europe from Northern Africa via the Mediterranean Sea or overland from the Middle East via Southeast Europe. The flow of refugees had started years ago, but came to full crisis when millions flocked to Europe in 2015. The sheer numbers of migrants entering EU countries - which for many member states reflected a 100-800\% increase in asylum applications from the previous year (Eurostat 2016) - presented a difficult tension between humanitarian and economic considerations. The free movement of peoples within the Schengen Area, combined with the depth of economic integration achieved in the single market, meant that the massive influx of undocumented migrants could not be the problem of a single country or group of countries, as the fact of open borders meant that undocumented migrants could move easily between Schengen countries. The lack of clear EU response to this crisis - indeed, the lack of consensus among member states whether there even ought to be a common EU response - caused further damage to the coherence of the European integration project. Member states responded differently to the call for a common approach. Some member states took on more refugees than others, in particular Germany and Sweden. Various countries that joined the EU in 2004 were more reluctant and opposed the EU quota system. Some member states reinstated border controls in an attempt to contain the flow of migrants from different directions. Compounding these problems, the rise of identity politics in many places fuelled public discontent and reinforced political perceptions of Muslim populations in Europe.

The migrant crisis on its own could theoretically represent a variety of crisis that is acute, but shortterm, and likely without long-term injury to the integrity of the EU as a supranational organization. Three considerations would support this view. First, this crisis began with events external to the EU and its member states. As opposed to the euro area crisis, which is rooted in the structure of EMU and thus in decisions made by European policy-makers, the migrant crisis is the result of externalities that lie much more beyond the EU's purview or immediate control. This characteristic puts the pressure of the crisis on response tactics, but lessens the need to justify the entire undertaking of EU integration. Put another way, the crisis may well have taken place whether the EU existed as a supranational entity or not. Second, the variety of crisis in this case is inextricable from economics. The height of the migrant crisis during the summer of 2015 coincided with Greece facing sovereign default and the euro dipping in confidence (Otero-Iglesias 2016); the theoretical flipside of this overlap is that economic growth and stability could buffer the impact of the crisis. 
As numerous scholars have demonstrated, public perceptions of immigrants are more negative during periods of economic stagnation or decline, and/or where the economic threat is subjectively perceived (Sniderman et al. 2004; Goldstein and Peters 2014). Third, and again in contrast with the euro area crisis, the substance of the EU's response itself to the crisis has not yet significantly intruded into the domestic policy-making of most member states (with the exception of Greece) (European Commission 2017b). The migrant quota system proposed by the European Commission in 2015 sought to redistribute asylum seekers among all EU member states. However, after swift and consistent opposition from the Visegrád Group (Czech Republic, Hungary, Poland, and Slovakia), the redistribution system was all but abandoned in 2016 (Gotev 2016). The reinstatement of border controls by numerous EU and Schengen members, as a way of attempting to control the flow of migrants, has been met with concern. Perhaps remarkably, the European Commission did not intervene, and it did not even deliver outright criticism (The Economist 2016). Both of these examples illustrate the tenacity of national sovereignty. These examples are evidence of the fragility of the EU level of authority on certain topics such as the migrant crisis - although one reason might be that it has been framed as a disaster outside of the EU's making.

A central indirect effect of the migrant crisis has been the sharp rise of populism as a dynamic political platform across numerous European countries. The term "populism" here is that of a "thin ideology" used by Mudde (2004), referring to a general framework that contrasts a pure people with a corrupt elite. The orientation of a populist political party can vary from nationalist to agrarian, far-right to socialist; the unifying strategy is that of appealing to the masses as a source of authority apart from existing institutions (Müller 2016). In the context of the EU, where legitimacy rests almost entirely upon indirect representation and technocratic authority, the increase in popularity of populist ideologies presents a significant challenge by way of underlying objections to the status quo. This is most evident in the political parties that have given shape to populism across EU member states. The specific platforms of such parties vary according to national context (prominent examples here include anti-immigration, anti-Islam, and the return to national protectionism), but one cohesive theme is the rejection of European integration. If populist sentiment represents opposition to globalist, cosmopolitan liberalism, the EU becomes clearly emblematic of all that populism rejects.

The actual variety of crisis that the rise of populism represents is, however, unclear. While populism as an expression represents an ideological challenge, the level of threat is entirely contained in the substance of the practical challenge and in the actual possibility of change. The strength of the crisis of populism is that it is helpful in elucidating when and how the decisions of those in power appear to be disconnected from voters across the EU; or, put another way, the notion that populist expression itself presents a crisis is entirely rooted in the social construction of whether the status quo of democratic institutions is legitimate. In this sense, populism is perhaps the more recent incarnation of expression of discontent with a democratic deficit. In light of the Oxford Dictionary's above definition of 'crisis,' the rise of populism could represent the "turning point of a disease when an important change takes place," i.e., the ability of the EU to adapt to the challenges that populism elucidates could, in the long term, actually help strengthen the representative capacities of the EU in its experiment in successful transnational governance. At present, populist ideology serves as a powerful source of protest, but has yet to govern as the new status quo, or even to present viable alternatives. Until such a turning point, the rise of populism could be understood in the EU context as a form of crisis that offers opportunities rather than full- 
scale chaos; however, the durability of these parties arguably reflects a shift in ideological acceptability within large swaths of European citizens, irrespective of electoral outcomes.

The Brexit crisis was connected to both the euro area crisis and the refugee crisis in that the United Kingdom (UK) government and most of its citizens had, over the past years, been more skeptical about European integration, and in particular, about steps towards deepening it, than any of the other member states. National leaders and UK media were often quick to point a finger at the EU as the cause of any domestic issue. However, at the heart of Brexit lies a domestic issue firmly rooted in the Conservative party and in strategic moves taken by British politicians (Staiger and Martill 2018). The past year has shown that the UK has not been afraid to move towards a 'hard Brexit,' which makes its break from the EU more monumental than if it had agreed to a relationship that resembles that of Norway or Switzerland. The variety of crisis with Brexit is that of a shock, but one with potential for substantive change in how the remaining 27 member states are able to conceptualize the role of EU governance. By becoming the first EU member to invoke article 50 of the Lisbon Treaty (giving notice of its intent to withdraw from the EU), the UK has set a precedent. In this sense, Brexit is more a crisis of the myth of ongoing and 'successful' European integration than foreshadowing necessarily a crisis of the EU (although the jury is still out; see Cini and Verdun 2018). In the early days after the Brexit referendum, some also wondered whether it would have a domino effect, that is, if political movements in other member states would seek a referendum to leave the EU. But 18 months hence, such a scenario seems less likely in the short term. Beyond this crisis of myth, the level of danger presented by Brexit towards the structural and ideational integrity of the EU is nominal. Rather, it offers opportunity for change in the style and substance of supranational governance.

\section{Conclusion}

The notion that European integration adapts in response to crisis offers a different outlook on the four crises outlined above. The history of the EU offers numerous examples of how a major event affected the decisions of policy-makers and changed the previously-intended direction of European integration. The euro area crisis, migrant crisis, rise of populism, and Brexit all fall into this broad category of events preceding change. The central difference is that all four of these events have been occurring at roughly the same time, and all are the result of many factors that are at once local, domestic, European, and global. As such, these particular four crises interact with each other, particularly when considering the depth and quality of legitimacy in European governance. Taken together as a parcel in the current moment, these four crises may seem to paint a picture of the EU as a flailing experiment in supranational authority that cannot compete with the durability and reliability of a national government. But as has been seen when analysing other EU crises, the developments away from the eye-catching news headlines may still paint a different picture.

The context of 'variety of crises' offers a different perspective on the challenges that each event presents. Considering crisis as a spectrum ranging from problem to full chaos, and marrying the journalistic portrayal of crisis with the possibility for significant change, we can see that the euro area crisis, migrant crisis, rise of populism, and Brexit in turn each offer different challenges and opportunities for the future direction of the EU. It should also be noted that the very idea of a crisis is frequently political and convenient; it is an idea used by political actors, those invested in the existence and the power of the EU, to draw attention to the need to have the EU and to enable it to 
be most effective. In so doing, it may also seek to turn the discussion away from basic intergovernmental accountability. As such, this type of construction of a crisis by EU leaders and their response is not that different from politics as usual in any self-contained nation-state. In this sense, the very notion of 'crisis' is ripe for critique in and of itself, and leaders are prone to use a crisis to draw power to the centre, either temporarily, or with a view to changing institutions for the longer term.

The theme of this special issue is the consequences of crises in the current context of the EU. Bookending this special issue, the pieces by both Cherry and Drago speak to the EU's need to deal with contestation. Cherry addresses the long-standing debate on democratic deficit to offer a novel strategy on bridging the gap between citizens and policy-makers - that of radical democratization while maintaining the strength of the supranational level. Drago addresses the rise of populism across European countries, and suggests that, in order to survive, the EU must actually embrace populist tendencies to strengthen its own commitment to peace and prosperity. In addressing the crisis of the euro area, Climie and Foster each examine the institutional repercussions of financial crisis in Europe. Climie's examination of the EU's mimicking of IMF institutional tools and Foster's comparative assessment of financial securities regulation tools developed as a euro area response both attend to the implications of basic economic decisions that affect society as a whole, which - in the EU case - are perceived to be removed from democratic choice, but that actually repeat institutional manoeuvres that have taken place in other countries in other parts of the world.

The theme connecting this Introduction with the articles contained in this special issue is the ongoing contestation of legitimate authority in each stage of each crisis. The public discomfort with supranational governance combined with the fragmented nature of European integration has resulted in the prioritization of legitimacy and subsidiarity over effectiveness. This "postfunctionalist" response (Hooghe and Marks 2009) is attentive to the long-simmering accusation of an EU democratic deficit, and yet limits the capacity of EU governance to advance in response to crisis. As such, à la Monnet, Europe will indeed be the sum of its responses to crisis, but the result thus far is more of a dynamic experiment, rather than a clear trajectory towards the growth of supranationalism. 


\section{REFERENCES}

Bayoumi, Tamim A., and Barry J. Eichengreen. 1994. "One Money or Many? On Analyzing the Prospects for Monetary Unification in Various Parts of the World." Princeton Studies in International Finance 76: International finance section, Princeton.

Cini, Michelle, and Amy Verdun.2018. "The Implications of Brexit for the Future of Europe.” In Brexit and Beyond: Rethinking the Futures of Europe and Beyond, edited by Uta Staiger and Benjamin Martill. London: UCL Press.

Crombez, Christophe. 2003. "The Democratic Deficit in the European Union: Much Ado about Nothing?” European Union Politics 4 (1): 101-120.

De Witte, Bruno. 2005. "The Process of Ratification and the Crisis Options: A Legal Perspective." In The EU Constitution: The Best Way Forward?, edited by Deirdre Curtin, Alfred E. Kellermann and Steven Blockmans, 21-38. The Hague: T.M.C. Asser Press.

Dinan, Desmond. 2010. Ever Closer Union: An Introduction to European Integration, 4th edition. New York: Palgrave.

Dyson, Kenneth. 1994. Elusive Union: The Process of Economic and Monetary Union in Europe. London and New York: Longman.

The Economist. 2016. "Forming an Orderly Queue." February 6. Accessed April 252017. http://www.economist.com/news/briefing/21690066-europe-desperately-needs-controlwave-migrants-breaking-over-its-borders-how.

European Commission. 2017a. "Public Opinion in the European Union. First Results" Standard Eurobarometer. No 87. Brussels: European Commission.

- 2017b. 'The ESM Stability Support Programme. Greece, First \& Second Reviews, July 2017 Background Report. Institutional Paper 064, European Economy, November. https://ec.europa.eu/info/sites/info/files/economy-finance/ip064 en.pdf

Eurostat. 2016. "News Release: Asylum in the EU Member States." March 4. http://ec.europa.eu/eurostat/documents/2995521/7203832/3-04032016-APEN.pdf/790eba01-381c-4163-bcd2-a54959b99ed6.

Feldstein, Martin. 1997. "EMU and International Conflict.” Foreign Affairs 76 (6): 60-73. Giddens, Anthony. 1999. "Risk and Responsibility." The Modern Law Review 62 (1): 1-10.

Goldstein, Judith L., and Margaret E. Peters. 2014. "Nativism or Economic Threat: Attitudes Towards Immigrants During the Great Recession.” International Interactions 40 (3): 376401. 
Gotev, Georgi. 2016. "Schultz admits mandatory relocation of refugees has failed." EurActiv, September 16. https://www.euractiv.com/section/justice-home-affairs/news/schulz-admitsmandatory-relocation-of-refugees-has-failed/.

Habermas, Jürgen. 2012. The Crisis of the European Union: A Response. Translated by Ciaran Cronin. UK: Polity Press.

Hallerberg, Mark, Benedicta Marzinotto, and Guntram B. Wolff. 2012. "On the Effectiveness and Legitimacy of EU Economic Policies.” Bruegel Policy Brief 2012/04, November 9. http://bruegel.org/2012/11/on-the-effectiveness-and-legitimacy-of-eu-economic-policies/.

Hansen, Lene, and Michael C. Williams. 1999. "The Myths of Europe: Legitimacy, Community and the 'Crisis' of the EU." Journal of Common Market Studies 37 (2): 233-249.

Hooghe, Liesbet, and Gary Marks. 2009. “A Postfunctionalist Theory of European Integration: From Permissive Consensus to Constraining Dissensus." British Journal of Political Science 39 (1): 1-23.

Hurrelmann, Achim. 2014. "Democracy Beyond the State: Insights from the European Union." Political Science Quarterly 129 (1): 87-105.

Hutter, Bridget M., and Sally Lloyd-Bostock. 2013. "Risk, Interest Groups and the Definition of Crisis: The Case of Volcanic Ash.” The British Journal of Sociology 64 (3): 383-404.

Inglehart, Ronald. 1967. “An End to European Integration?” American Political Science Review 61 (1): 91-105.

Ioannou, Demostenes, Patrick Leblond, and Arne Niemann. 2015. "European integration and the crisis: practice and theory.” Journal of European Public Policy 22 (2): 155-176.

Italianer, Alexander. 1993. "Mastering Maastricht: EMU Issues and How They Were Settled." In Economic and Monetary Union: Implications for National Policy-Makers, edited by Klaus Gretschmann, 68-70. Maastricht: European Institute of Public Administration.

Jacqué, Jean-Paul. 1991. "German Unification and the European Community”. European Journal of International Law 2 (1): 1-16.

Jones, Erik, and Matthias Matthijs. 2017. "Democracy without Solidarity: Political Dysfunction in Hard Times - Introduction to Special Issue.” Government and Opposition 52 (2): 185-210.

Jones, Erik, Daniel Kelemen, and Sophie Meunier. 2015. "Failing Forward? The Euro Crisis and the Incomplete Nature of European Integration.” Comparative Political Studies 49 (7): 10101034.

Krugman, Paul. 1993. "Six Skeptical Propositions About EMU.” Greek Economic Review 15 (1): 93-104. 
Laursen, Finn, and Sophie Vanhoonacker. 1994. The Ratification of the Maastricht Treaty: Issues, Debates and Future Implications. Dordrecht: Martinus Nijhoff.

Ludlow, N. Piers. 1999. "Challenging French Leadership in Europe: Germany, Italy, the Netherlands and the Outbreak of the Empty Chair Crisis of 1965-1966." Contemporary European History 8 (2): 231-248.

- 2006. The European Community and the Crises of the 1960s: Negotiating the Gaullist Challenge. London: Routledge.

Matthijs, Matthias, and Mark Blyth. 2015. The Future of the Euro. Oxford: Oxford University Press.

Mény, Yves. 2014. "Managing the EU Crises: Another Way of Integration by Stealth?" West European Politics 37 (6): 1336-1353.

Menz, George, and Mitchell P. Smith. 2013. "Kicking the Can Down the Road to More Europe? Salvaging the Euro and the Future of European Economic Governance." Journal of European Integration 35 (3): 195-206.

Mudde, Cas. 2004. “The Populist Zeitgeist.” Government and Opposition 39 (4): 541-563.

Müller, Jan-Werner. 2016. What is Populism? Philadelphia: University of Pennsylvania Press.

Offe, Claus. 2015. Europe Entrapped. Cambridge: Polity Press.

Otero-Iglesias, Miguel (ed.). 2016. "Lessons from the Grexit Debate in 2015," Collection of short articles first published as academic symposium in the 2015 Winter Newsletter edited by the Political Economy Interest Section of the European Union Studies Association (EUSA); reprinted:

http://www.realinstitutoelcano.org/wps/wcm/connect/dfdbd4804b70ac34b09cb3eeaa369ed c/Lessons-from-Grexit-Debate-2015.pdf?MOD=AJPERES\&cacheid=1453721325133 $\quad$ (25 January 2016).

Oxford English Dictionary. 2017. “art, n.1.” OED Online. March 2017. Oxford University Press. Accessed April 6 2017. http://www.oed.com/viewdictionaryentry/Entry/11125.

Özlem Atikcan, Ece. 2015. Framing the European Union, Cambridge: Cambridge University Press.

Sandholtz, Wayne. 1993. "Choosing Union: Monetary Politics and Maastricht." International Organization 47 (1): 1-39.

Schimmelfennig, Frank. 2015. "Liberal Intergovernmentalism and the Euro Area Crisis.” Journal of European Public Policy 22 (2): 177-195. 
Schmidt, Vivien A. 2014. "Speaking to the Markets or to the People? A Discursive Institutionalist Analysis of the EU's Sovereign Debt Crisis." British Journal of Politics and International Relations 16 (1): 188-209.

Schmitter, Philippe C. 1970. "A Revised Theory of Regional Integration," International Organization, 24 (4): 836-868.

- 2000. How to Democratize the European Union - and Why Bother? Lanham: Rowman and Littlefield.

Schure, Paul, and Amy Verdun. 2018. "The Single Market and Economic and Monetary Integration." In European Union Governance and Policy Making: A Canadian Perspective, edited by Emmanuel Brunet-Jailly, Achim Hurrelmann, and Amy Verdun, Chapter 7. Toronto: University of Toronto Press.

Sniderman, Paul M., Louk Hagendoorn, and Markus Prior. 2004. "Predisposing Factors and Situational Triggers: Exclusionary Reactions to Immigrant Minorities." American Political Science Review 98 (1): 35-49.

Staiger, Uta, and Benjamin Martill (eds). 2018. Brexit and Beyond: Rethinking the Futures of Europe and Beyond, London: UCL Press.

Stavridis, Stelios, and Amy Verdun. 2001. "Democracy in the Three Pillars of the EU." Current Politics and Economics of Europe 10 (3): 213-349.

Stone Sweet, Alec, and Wayne Sandholtz. 1997. "European Integration and Supranational Governance.” Journal of European Public Policy 4 (3): 297-317.

Verdun, Amy. 1998. “The Institutional Design of EMU: A Democratic Deficit?” Journal of Public Policy 18 (2): 107-132.

1999. "The Role of the Delors Committee in the Creation of EMU: An Epistemic Community?" Journal of European Public Policy 6 (2): 308-28.

- 2000. European Responses to Globalization and Financial Market Integration. Palgrave Macmillan.

Verdun, Amy, and Jonathan Zeitlin. 2017. "Introduction: the European Semester as a New Architecture of EU Socioeconomic Governance in Theory and Practice." Journal of European Public Policy, 1-12. DOI: https://doi.org/10.1080/13501763.2017.1363807.

Worre, Torben. 1995. "First No, Then Yes: The Danish Referendums on the Maastricht Treaty 1992 and 1993.” JCMS: Journal of Common Market Studies 33 (2): 235-57.

Zielonka, Jan. 2014. Is the EU Doomed? Cambridge: Polity Press. 
Published by the Centre for European Studies at Carleton University, Ottawa, Canada Available online at: journals.carleton.ca/rera/index.php/rera

RERA is an electronic academic peer-reviewed journal that publishes graduate, post-graduate, and young scholarly works. Topics relate to the European Union, its Member States, the former Soviet Union, and Central and Eastern Europe. The journal is a joint project supported by the CanadaEurope Transatlantic Dialogue - a cross-Canada research network supported by the Social Sciences and Humanities Research Council of Canada (SSHRC) — along with the Institute of European, Russian and Eurasian Studies (Carleton University) and its associated research unit, the Centre for European Studies.

RERA aims to provide an accessible forum for research, to promote high standards of research and scholarship, and to foster communication among young scholars.

\section{Contact:}

Carleton University

The Centre for European Studies

1103 Dunton Tower

1125 Colonel By Drive

Ottawa, ON K1S 5B6

Canada

Tel: +01 613 520-2600 ext. 3117; E-mail: rera-journal@ carleton.ca

\section{Creative Commons License}

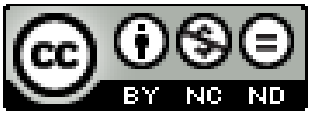

creativecommons.org/licenses/by-nc-nd/3.0

This Working Paper is licensed under a Creative Commons Attribution-Non-CommercialNo Derivs 3.0 Unported License (CC BY-NC-ND 3.0).

Articles appearing in this publication may be freely quoted and reproduced, provided the source is acknowledged. No use of this publication may be made for resale or other commercial purposes.

ISSN: 1718-4835

(C) 2018 The Author(s) 